\title{
Aurantimonas altamirensis sp. nov., a member of the order Rhizobiales isolated from Altamira Cave
}

Correspondence

Juan M. Gonzalez

jmgrau@irnase.csic.es

\author{
Valme Jurado, Juan M. Gonzalez, Leonila Laiz and Cesareo Saiz-Jimenez
}

Instituto de Recursos Naturales y Agrobiologia, CSIC, Apartado 1052, 41080 Sevilla, Spain

\begin{abstract}
A bacterial strain, $\mathrm{S} 1 \mathrm{~B}^{\top}$, was isolated from Altamira Cave (Cantabria, Spain). The cells were Gramnegative, short rods growing aerobically. Comparative 16S rRNA gene sequence analysis revealed that strain $\mathrm{S} 21 \mathrm{~B}^{\top}$ represented a separate subline of descent within the family 'Aurantimonadaceae' (showing $96 \%$ sequence similarity to Aurantimonas coralicida) in the order Rhizobiales (Alphaproteobacteria). The major fatty acids detected were $\mathrm{C}_{16: 0}$ and $\mathrm{C}_{18: 1} \omega 7 \mathrm{c}$. The $\mathrm{G}+\mathrm{C}$ content of the DNA from strain $\mathrm{S}_{21 \mathrm{~B}^{\top}}$ was $71.8 \mathrm{~mol} \%$. Oxidase and catalase activities were present. Strain $\mathrm{S}^{21 \mathrm{~B}^{\mathrm{T}}}$ utilized a wide range of substrates for growth. On the basis of the results of this polyphasic study, isolate $S 21 \mathrm{~B}^{\top}$ represents a novel species of the genus Aurantimonas, for which the name Aurantimonas altamirensis sp. nov. is proposed. The type

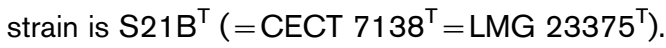

The genera Aurantimonas and Fulvimarina constitute the two members of the recently described family 'Aurantimonadaceae' within the order Rhizobiales. Both genera are represented by single species, Aurantimonas coralicida (Denner et al., 2003) and Fulvimarina pelagi (Cho \& Giovannoni, 2003), which were isolated from the marine environment. A. coralicida was isolated from a diseased coral (Dichocoenia stokesi) and F. pelagi was retrieved from bacterioplankton; at present, there are no members of this family from terrestrial environments.

This paper reports on the isolation and characterization of strain $\mathrm{S} 21 \mathrm{~B}^{\mathrm{T}}$. This strain was collected from a subterranean environment, Altamira Cave (Cantabria, Spain), being part of a complex microbial community that produces whitecoloured colonization on the walls of the cave. This whitecoloured microbial growth is threatening the important Palaeolithic paintings of Altamira Cave (Gonzalez et al., 2006).

Strain $\mathrm{S} 21 \mathrm{~B}^{\mathrm{T}}$ was isolated on 1000-fold-diluted tryptose soy agar (TSA; Oxoid) at $28^{\circ} \mathrm{C}$. A. coralicida DSM $14790^{\mathrm{T}}$ and $F$. pelagi DSM $15513^{\mathrm{T}}$ were grown on marine agar 2216 (Difco, Becton Dickinson). The methods used in this study were performed as described previously (Jurado et al., 2005a, b), except where indicated otherwise. The cellular fatty acids were determined as described by Gonzalez et al. (2004), using the same growth conditions for the tested strains. The growth temperature was tested in the range $4-46^{\circ} \mathrm{C}$. Tolerance of $\mathrm{NaCl}$ was studied on TSA and in nutrient broth each supplemented with 0-25\% (w/v) NaCl. Pigment analysis was performed as reported by Denner et al. (2003).

The GenBank/EMBL/DDBJ accession number for the $16 \mathrm{~S}$ rRNA gene sequence of strain $\mathrm{S}^{2} 1 \mathrm{~B}^{\top}$ is DO372921.
Analysis of $16 \mathrm{~S}$ rRNA gene sequences revealed that strain $\mathrm{S} 21 \mathrm{~B}^{\mathrm{T}}$ belongs to the family 'Aurantimonadaceae' and is closely related to the members of the genera Aurantimonas (96.1\% similarity) and Fulvimarina (93.2\% similarity). Within this phylogenetic clade, the members of the genera Aurantimonas and Fulvimarina showed $93.8 \%$ similarity. Phylogenetic analysis based on 1293 bp was performed as described previously (Jurado et al., 2005b). A consensus tree showed the $16 \mathrm{~S}$ rRNA gene sequence of strain $\mathrm{S} 21 \mathrm{~B}^{\mathrm{T}}$ branching off in the proximity of $A$. coralicida strains (not shown). Thus, strain $S 21 \mathrm{~B}^{\mathrm{T}}$ represents the first member of this family to have been isolated from a terrestrial environment.

Strain $\mathrm{S} 21 \mathrm{~B}^{\mathrm{T}}$ grows optimally in nutrient agar without the addition of salts and at salt concentrations below $20 \mathrm{~g} \mathrm{l}^{-1}$; these values for salt concentration were lower than the optimum values observed for the type strains of $A$. coralicida (32 $\mathrm{g} \mathrm{l}^{-1}$; Denner et al., 2003) and F. pelagi (20-25 $\mathrm{g} \mathrm{l}^{-1}$; Cho \& Giovannoni, 2003). The maximum NaCl concentration tolerated by strain $\mathrm{S} 21 \mathrm{~B}^{\mathrm{T}}$ was $50 \mathrm{~g} \mathrm{l}^{-1}$. Growth of $A$. coralicida and $F$. pelagi occurred at $4-40{ }^{\circ} \mathrm{C}$, while strain $\mathrm{S} 21 \mathrm{~B}^{\mathrm{T}}$ showed significant growth between 10 and $40^{\circ} \mathrm{C}$, with an optimum at $28^{\circ} \mathrm{C}$. The cells of strain $\mathrm{S} 21 \mathrm{~B}^{\mathrm{T}}$ were Gramnegative, strictly aerobic, non-spore-forming, non-motile, short rods, whereas $A$. coralicida $\mathrm{WP}^{\mathrm{T}}$ showed motility. No flagella were observed on negatively stained cells of strain $\mathrm{S} 21 \mathrm{~B}^{\mathrm{T}}$. The novel strain was oxidase- and catalase-positive. Other morphological and physiological characteristics of strain $\mathrm{S}_{2} 1 \mathrm{~B}^{\mathrm{T}}$ are shown in Table 1. The hydrolysis of adenine, hypoxanthine, tyrosine, xanthine and Tweens 20 and 80 differed among the analysed type strains and $\mathrm{S} 21 \mathrm{~B}^{\mathrm{T}}$. A. coralicida $\mathrm{WP}^{\mathrm{T}}$ and strain $\mathrm{S} 21 \mathrm{~B}^{\mathrm{T}}$ could be clearly differentiated on the basis of the production of acid from erythritol and L-xylose; a longer list of substrates utilized 
Table 1. Phenotypic characteristics of strain $\mathrm{S}_{2} 1 \mathrm{~B}^{\top}$ and related type strains

Strains: 1, strain $\mathrm{S}_{21 \mathrm{~B}^{\mathrm{T}}}$; 2, A. coralicida DSM $14790^{\mathrm{T}}$; 3, F. pelagi DSM $15513^{\mathrm{T}}$. Symbols: -, negative; + , positive; $(+)$, weakly positive. Data were obtained during this study under identical growth conditions, except where indicated otherwise. Strain $\mathrm{S} 21 \mathrm{~B}^{\mathrm{T}}$ produces acid from D-glucose and D-fucose. It produces alkaline phosphatase, esterase $(\mathrm{C} 1)$, esterase lipase $(\mathrm{C} 8)$, leucine arylamidase, acid phosphatase and naphthol-AS-BI-phosphohydrolase but not lipase (C14), cystine arylamidase, $\alpha$-chymotrypsin, $\alpha$ galactosidase, $\beta$-galactosidase, $\beta$-glucuronidase, $\alpha$-glucosidase, $\beta$-glucosidase, $N$-acetyl- $\beta$-glucosaminidase, $\alpha$-mannosidase or $\alpha$-fucosidase. It assimilates mannose, malate, gluconate and glucose but not capric acid, adipic acid or citrate. It is positive for catalase and oxidase. It is positive for urease activity and negative for glucose fermentation and arginine dihydrolase activity. It is negative for the hydrolysis of aesculin, gelatin and starch, for nitrate reduction and in Voges-Proskauer, methyl red and indole tests. It is sensitive to chloramphenicol $(30 \mu \mathrm{g})$, rifampicin $(5 \mu \mathrm{g})$, tetracycline $(30 \mu \mathrm{g})$, norfloxacin $(10 \mu \mathrm{g})$, novobiocin $(30 \mu \mathrm{g})$, streptomycin $(10 \mu \mathrm{g})$, carbenicillin $(100 \mu \mathrm{g})$, framycetin $(50 \mu \mathrm{g})$, nalidixic acid $(30 \mu \mathrm{g})$ and erythromycin $(15 \mu \mathrm{g})$. Halophilic growth (at $10 \% \mathrm{NaCl})$ is an additional trait that could be useful in discriminating between Aurantimonas and Fulvimarina species.

\begin{tabular}{|c|c|c|c|}
\hline Characteristic & 1 & 2 & 3 \\
\hline Growth with $10 \% \mathrm{NaCl}(\mathrm{w} / \mathrm{v})$ & - & - & + \\
\hline \multicolumn{4}{|l|}{ Decomposition or hydrolysis of: } \\
\hline Adenine & + & - & + \\
\hline Hypoxanthine & + & - & + \\
\hline Tyrosine & - & - & + \\
\hline Xanthine & + & - & + \\
\hline Tween 20 & - & + & - \\
\hline Tween 80 & - & + & - \\
\hline \multicolumn{4}{|l|}{ Acid produced from: } \\
\hline D-Arabinose & $(+)$ & + & - \\
\hline L-Arabinose & + & + & - \\
\hline Erythritol & + & - & - \\
\hline L-Fucose & $(+)$ & - & - \\
\hline D-Galactose & + & + & - \\
\hline Gentiobiose & - & $(+)$ & - \\
\hline D-Mannose & + & + & - \\
\hline D-Melibiose & $(+)$ & + & - \\
\hline L-Rhamnose & + & + & - \\
\hline D-Ribose & + & + & - \\
\hline D-Xylose & + & + & - \\
\hline L-Xylose & - & + & - \\
\hline \multicolumn{4}{|l|}{ Assimilation of: } \\
\hline Arabinose & + & $+{ }^{a_{\star}}$ & - \\
\hline Maltose & + & - & + \\
\hline Mannitol & + & - & - \\
\hline $\mathrm{N}$-Acetylglucosamine & + & - & + \\
\hline Phenylacetic acid & - & - & + \\
\hline \multicolumn{4}{|l|}{ Antibiotic susceptibility } \\
\hline Ampicillin $(10 \mu \mathrm{g})$ & + & - & - \\
\hline Doxycycline $(30 \mu \mathrm{g})$ & + & - & + \\
\hline Kanamycin $(30 \mu \mathrm{g})$ & + & $+{ }^{a}$ & $-{ }^{b}$ \\
\hline Vancomycin $(30 \mu \mathrm{g})$ & - & - & + \\
\hline Gentamicin $(10 \mu \mathrm{g})$ & + & $+{ }^{a}$ & $-{ }^{b}$ \\
\hline \multicolumn{4}{|l|}{ Enzymic activities } \\
\hline$\beta$-Glucosidase & - & - & + \\
\hline Trypsin & + & - & - \\
\hline
\end{tabular}

${ }^{\star}$ Data from other studies indicated as: $a$, Denner et al. (2003); b, Cho \& Giovannoni (2003). 
Table 2. Major fatty acid composition of strain $\mathrm{S} 1 \mathrm{~B}^{\top}$ and related type strains

Strains: 1, strain $\mathrm{S} 1 \mathrm{~B}^{\mathrm{T}} ; 2$, A. coralicida DSM $14790^{\mathrm{T}} ; 3$, F. pelagi DSM $15513^{\mathrm{T}}$. Data were obtained during this study under identical growth conditions. ND, Not detected.

\begin{tabular}{|lccc|}
\hline Fatty acid & $\mathbf{1}$ & $\mathbf{2}$ & $\mathbf{3}$ \\
\hline $\mathrm{C}_{16: 0}$ & $11 \cdot 3 \pm 0 \cdot 1$ & $6 \cdot 2 \pm 0 \cdot 0$ & $5 \cdot 2 \pm 0 \cdot 0$ \\
iso- $\mathrm{C}_{16: 0}$ & $1 \cdot 4 \pm 0 \cdot 0$ & $\mathrm{ND}$ & $\mathrm{ND}$ \\
$\mathrm{C}_{18: 0}$ & $0 \cdot 7 \pm 0 \cdot 0$ & $2 \cdot 0 \pm 0 \cdot 0$ & $12 \cdot 7 \pm 0 \cdot 9$ \\
$\mathrm{C}_{18: 1} 2-\mathrm{OH}$ & $3 \cdot 5 \pm 0 \cdot 1$ & $3 \cdot 2 \pm 0 \cdot 0$ & $1 \cdot 2 \pm 0 \cdot 0$ \\
$\mathrm{C}_{18: 1} \omega 7 c$ & $74 \cdot 4 \pm 0 \cdot 2$ & $69 \cdot 4 \pm 0 \cdot 0$ & $77 \cdot 2 \pm 0 \cdot 2$ \\
$\mathrm{C}_{19: 0} \omega 8 c$ cyclo & $\mathrm{ND}$ & $13 \cdot 2 \pm 0 \cdot 0$ & $2 \cdot 9 \pm 0 \cdot 3$ \\
\hline
\end{tabular}

differently by $F$. pelagi HTCC $2506^{\mathrm{T}}$ and strain $\mathrm{S} 21 \mathrm{~B}^{\mathrm{T}}$ is shown in Table 1. Strain $\mathrm{S}_{2} 1 \mathrm{~B}^{\mathrm{T}}$ was able to assimilate maltose, mannitol and $\mathrm{N}$-acetylglucosamine, whereas $A$. coralicida $\mathrm{WP} 1^{\mathrm{T}}$ was unable to utilize these substrates. Strain $\mathrm{S} 21 \mathrm{~B}^{\mathrm{T}}$ could also be differentiated from the A. coralicida and $F$. pelagi type strains on the basis of antibiotic susceptibilities (Table 1). Strain $\mathrm{S} 21 \mathrm{~B}^{\mathrm{T}}$ produced carotenoid pigments with peaks in the absorption spectra at 447 and $470-471 \mathrm{~nm}$, with a slight inflexion point at $424-427 \mathrm{~nm}$, similar to $A$. coralicida and $F$. pelagi.

The major fatty acids detected in strain $\mathrm{S} 21 \mathrm{~B}^{\mathrm{T}}$ are shown in Table 2. The predominant fatty acid in strain $\mathrm{S} 21 \mathrm{~B}^{\mathrm{T}}$ was cis7-octadecenoic acid $\left(\mathrm{C}_{18: 1} \omega 7 c\right)$, as was the case for $A$. coralicida and F. pelagi. However, strain $\mathrm{S}_{2} 1 \mathrm{~B}^{\mathrm{T}}$ and these species showed significant differences in the content of $\mathrm{C}_{19: 0} \omega 8 c$ cyclo, iso- $\mathrm{C}_{16: 0}, \mathrm{C}_{16: 0}, \mathrm{C}_{18: 0}$ and $\mathrm{C}_{18: 1} \omega 7 c$, as shown in Table 2.

The DNA $\mathrm{G}+\mathrm{C}$ content of strain $\mathrm{S} 21 \mathrm{~B}^{\mathrm{T}}$ was $71 \cdot 8 \pm 1 \cdot 8 \mathrm{~mol} \%$, which is slightly higher than the value for A. coralicida $\mathrm{WP}^{\mathrm{T}}$ ( $66 \cdot 3 \mathrm{~mol} \%$; Denner et al., 2003) and much higher than those for $F$. pelagi strains (57.6-59.9 mol\%; Cho \& Giovannoni, 2003). The degrees of DNA-DNA relatedness between strain $\mathrm{S}_{2} 1 \mathrm{~B}^{\mathrm{T}}$ and the type strains of $A$. coralicida and $F$. pelagi were determined using DNA from strain $S 21 \mathrm{~B}^{\mathrm{T}}$ as a probe for DNA-DNA hybridization, according to the method described by Ziemke et al. (1998). A. coralicida $\mathrm{WP}^{\mathrm{T}}$ and F. pelagi HTCC $2506^{\mathrm{T}}$ showed DNA relatedness values of 56 and $46 \%$, respectively. The results regarding $\mathrm{G}+\mathrm{C}$ contents and DNA-DNA relatedness estimates confirmed that strain $\mathrm{S} 21 \mathrm{~B}^{\mathrm{T}}$ represents a novel genospecies that can be clearly differentiated from A. coralicida and F. pelagi.

On the basis of the phenotypic and genotypic characteristics described above and their differences with respect to those of previously described related species within the family 'Aurantimonadaceae', strain $\mathrm{S} 21 \mathrm{~B}^{\mathrm{T}}$ represents a novel species within the genus Aurantimonas, for which the name Aurantimonas altamirensis sp. nov. is proposed.

\section{Description of Aurantimonas altamirensis sp. nov.}

Aurantimonas altamirensis [al.ta.mi.ren'sis. N.L. fem. adj. altamirensis referring to Altamira Cave (Cantabria, Spain), where the type strain was isolated].

Gram-negative. Cells are non-motile, short rods, $0.9 \mu \mathrm{m}$ wide and $1 \cdot 1 \mu \mathrm{m}$ long on average. Strictly aerobic. Colonies are about $1 \mathrm{~mm}$ in diameter, yellow-coloured, circular, convex and smooth. Growth occurs between 10 and $40{ }^{\circ} \mathrm{C}$, growing optimally at $28^{\circ} \mathrm{C}$. The optimum $\mathrm{NaCl}$ concentration for growth is $0-20 \mathrm{~g} \mathrm{NaCl} \mathrm{l}^{-1}$; concentrations up to $50 \mathrm{~g} \mathrm{l}^{-1}$ are tolerated. Peaks in absorption spectra are as defined for the genus. Catalase-, oxidase- and ureasepositive. Chemotaxonomic characteristics are as reported in Table 1. The predominant fatty acid is $\mathrm{C}_{18: 1} \omega 7 c$, with significant proportions of $\mathrm{C}_{16: 0}, \mathrm{C}_{18: 1} 2-\mathrm{OH}$, iso- $\mathrm{C}_{16: 0}$ and $\mathrm{C}_{18: 0} ; \mathrm{C}_{19: 0} \omega 8 c$ cyclo is not detected. The DNA G+C content of the type strain is $71 \cdot 8 \mathrm{~mol} \%$.

The type strain, strain $\mathrm{S} 21 \mathrm{~B}^{\mathrm{T}}\left(=\mathrm{CECT} 7138^{\mathrm{T}}=\mathrm{LMG}\right.$ $23375^{\mathrm{T}}$ ), was isolated from Altamira Cave (Cantabria, Spain).

\section{Acknowledgements}

The authors acknowledge support through a contract with the Ministry of Culture. V. J. and J. M. G. are grateful for support from the I3P and Ramon y Cajal programs, respectively, from the Spanish Ministry of Education and Science (MEC).

\section{References}

Cho, J.-C. \& Giovannoni, S. J. (2003). Fulvimarina pelagi gen. nov., sp. nov., a marine bacterium that forms a deep evolutionary lineage of descent in the order 'Rhizobiales'. Int J Syst Evol Microbiol 53, 1853-1859.

Denner, E. B. M., Smith, G. W., Busse, H.-J., Schumann, P., Narzt, T., Polson, S. W., Lubitz, W. \& Richardson, L. L. (2003). Aurantimonas coralicida gen. nov., sp. nov., the causative agent of white plague type II on Caribbean scleractinian corals. Int J Syst Evol Microbiol 53, $1115-1122$.

Gonzalez, J. M., Jurado, V., Laiz, L., Zimmermann, J., Hermosin, B. \& Saiz-Jimenez, C. (2004). Pectinatus portalensis nov. sp., a relatively fast-growing, coccoidal, novel Pectinatus species isolated from a wastewater treatment plant. Antonie van Leeuwenhoek 86, 241-247.

Gonzalez, J. M., Portillo, M. C. \& Saiz-Jimenez, C. (2006). Metabolically active Crenarchaeota in Altamira Cave. Naturwissenschaften 93, 42-45.

Jurado, V., Groth, I., Gonzalez, J. M., Laiz, L. \& Saiz-Jimenez, C. (2005a). Agromyces salentinus sp. nov. and Agromyces neolithicus sp. nov. Int J Syst Evol Microbiol 55, 153-157.

Jurado, V., Laiz, L., Gonzalez, J. M., Hernández-Mariné, M., Valens, M. \& Saiz-Jimenez, C. (2005b). Phyllobacterium catacumbae sp. nov., a member of the order 'Rhizobiales' isolated from Roman catacombs. Int J Syst Evol Microbiol 55, 1487-1490.

Ziemke, F., Höfle, M. G., Lalucat, J. \& Rosselló-Mora, R. (1998). Reclassification of Shewanella putrefaciens Owen's genomic group II as Shewanella baltica sp. nov. Int J Syst Bacteriol 48, 179-186. 